\title{
THE CO-ORDINATION OF THE EU'S INTERNATIONAL POLICIES A HOST OF UNCERTAINTIES
}

\author{
Michael A. RUPp*
}

\section{Introduction}

Throughout the history of the European Community (EC), political scientists have been able to monitor its external effects. Yet while changes in the institutional framework via Treaty amendments, quasi- "judicial review" and political practice have continuously assigned more competences to the EC in the internal realm, there was little corresponding increase in its international competences. For the conduct of international policies the Member States made a formal distinction and devised a special mechanism different from the EC process per se.

The distinction read external policies as opposed to foreign relations and the mechanism was called European Political Co-operation (EPC). The distinction entrusted the "high-politics" to an informal co-operation with a dubious commitment and a factual absolute veto of the nation state, while it left the so called "low-politics" to the supranational level. "Low-politics" which were less sovereignty-sensitive like external commercial policy, development policy and generally the conduct of economic relations

The foundation for this distinction had already been eroded when the momentous events of 1989/1990 occured. The resulting immense challenge to Western Europe demonstrated the impossibility to maintain this separation'. The historically unprecedented task to support in parallel the transition to a market economy and a pluralist democracy projected the politico-economic nexus right into the heart of the

- Lecturer, University of Leeds, Centre for European Studies.

1 Holland, Martin. European Integration. p. 123. 
EC. The EC had to recognise this nexus and create the institutional foundations for a policy geared towards stabilising the region. The necessity for an overhaul of the European Treaties was widely recognised. Yet fundamental differences about the direction of change between the governments of the Member States and the lack of an "overriding and consistent constitutional philosophy", posed great difficulties for the Intergovernmental Conference (IGC) on Political Union in 1990/91, and the inception of the Treaty on European Union (TEU) ${ }^{3}$.

International relation scholars have already discussed the new foreign policy capacities of the European Union to 'act' in the international system. These analyses have usually focused exclusively on the structures for the newly assembled Common Foreign and Security Pillar (CFSP). Substantial criticism has been voiced about the extreme intergovernmental nature of the CFSP itself, whereas little if any attention has been paid to the compatibility of the CFSP with the EC structures. This article will argue that the problem of the EU's international actorness - a term to developed below - lies less in its intergovernmental outlook per se than in the sharp difference between a supranational and an intergovernmental conduct when it comes to the different facets of international action.

Following largely the definition of Sjöstedt ${ }^{5}$, an entity which possesses international actorness can be defined as: 1) delimited from others, and from its environment; 2) autonomous, which means making its own laws and decisions; and which 3) possesses certain structural prerequisites for action on the international level. With its clear definition of membership (with presently fitteen states) and the constitutional structure of the Treaties creating the institutions and awarding rights and duties to these Member States and their citizens, the EU is a crearly delimited entity. Secondly the Member States have already pooled their sovereignty in the policy-fields assigned to the European Union (EU) which makes its own laws and decisions, thus fulfilling Sjöstedt's second criterion. Finally it is precisely the third condition which the IGC on Political Union set out to meet. The reform of the institutions of the Community - or the Union as the construction was quickly christened - were supposed to increase coherence. Due to the discord of the Member States, however, this has not been achieved.

2 Curtin, Deirdre. The Constifutional Structure of the Union: A Europe of Bits and Pieces. pp. 17-18.

3 The TEU was concluded in Maastricht at the 7th of February 1992 and after problems with the ratification in several member states has taken effect at the 1st of November 1993.

4 Lodge, Juliel. From civilian power to speaking with a common voice: the transition to a CFSP. passim.

5 Sjöstedt, Gunnar. The Extemal Role of the European Community. (Cited after Hill, Christopher. The Capability-Expectations Gap, or Conceptualizing Europe's International role. pp. 308-309.) 
The purpose of this article is to demonstrate that under the Maastricht Treaty the EU is unable to show enough coherence to act effectively on the international stage, because the formulation of international politics is separated into EC and CFSP politics, and the mechanisms to bridge the gap between the conduct of the foreign and the external policies are insufficient ${ }^{6}$.

For this purpose the article has been divided into the following four chapters :

Chapter 1 will explain how several distinctions in international politics have become increasingly blurred. Amongst these are the afore mentioned distinction between "high-" and "low politics", the distinction between "foreign relations" and "external policies" and the distinction between policies having domestic effects on the one hand and having external effects on the other hand.

Chapter 2 will analyse the capacities which the TEU conveys for the EU. The subsection $2 \mathrm{~A}$. will focus on the overall constitutional structure of the TEU in order to shed light on the relation of the new pillars with the already existing EC. It transcribes the problematique of the artificial distinction into the EU/EC context. It will analyse if the TEU realizes its own objective, which is to increase the 'actorness' of the EU in international relations. As an example, the section scrutinises the capacities of the EU to conclude international treaties. Sub-section $2 \mathrm{~B}$. will analyse the differences in the institutional framework between the two pillars of the Union and the hence diverging policy-formulation capacities of the two structures in the field of foreign/ external policies. Finally, it will outline a typology of four different conceivable failures in the formulation phase of the EU foreign policy.

Chapter 3: Due to opposition by some Member States the TEU did not resort to the constitutional solution of coherence by unification of the political structure. The negotiators thus left the realisation of the EU's coherence to the institutions themselves, hoping for a coherence to occur by interaction. The chapter will analyse the chances of this strategy being realised, given the possibilities which the institutions of the Union have at their disposal. Mindful of the novelty of the process and the paucity of empirical evidence, the analysis will use analogies with the former institutional interaction under the EC/EPC regime for its evaluations. It will furthermore project that the organisational pattern likely to emerge out of the process is a modified form of engrenage or Politikverflechtung.

Chapter 4: In the final chapter I will draw the conclusion that with the engrenage development, the TEU has created a dilemma which makes it virtually im-

6 Often the terms EU and EC are used interchangably in the media or the EU is assumed to be the successor of the EC. In tact, however, the EC continues to exist as one of the three pillars within the EU. Throughout the text, 'EU' signifies the whole of the entity established by the TEU, while 'EC' signifies one of the pillars within it. 
possible to increase the EU's actorness based upon the strategy utilised by the IGC on Political Union.

\section{Chapter 1. Of out-dated definitions and void distinctions}

International Relations Theory established a distinction between the concepts "external relations", comprising - sometimes unintended - contacts and consequences by virtue of the very existence of an international actor and "4oreign policy" which implies "the existence of intently formulated and executed policies, based on both domestic and external considerations ${ }^{m 7}$. In reality, however, it is very problematic to draw the line between them.

In light of this definition the governments of the EC's Member States have had good reason for depriving the EC from having foreign policies. After all, the EC was not supposed to possess a "domestic realm" on behalf of which policies towards "4oreigners" could be intetly formulated. The distinction which assigned to the EC only external relations matched the distinction between "low-" and "high-politics" devised by functionalists in integration theor ${ }^{8}$. Sovereignty--sensitive issues, like security, defence and relations with other states were supposed to remain in the hand of the nation state, whereas "low"-politics, like foreign trade and competition policies, could be exerted by the EC. The whole basis of the EPC was founded upon the assumptions that these could be effectively separated.

Yet a process of factual restructuring has changed the international system and a process of notional restructuring has altered the perception of it. Both processes have in effect undermined several of the distinctions over the years:

When we look at the following two considerations, we see that the first casualty is the distinction between high- and low-politics :

National interest and public perception: Already the Cold War saw economic policies constantly increasing in their relevance. The increase in global competition raised active economic policies to a hitherto unknown place on the political agenda. As a consequence what was formerly. "low-politics" became indistinguishable from the original "high politics".

7 liestos, Panayiotis. European Political Cooperation. p.6.

8 Groom, A.J.R./Taylor, Paul. Functionalism. p. 20. Arguably the functionalist theorisis themselves did not intend this distinction to be always so cut and dry. The reality of the integration process was and still is much more complicaled than the easy distinction which was used in political battles. See: Lodge, Juliet. Preface. pp. xix-xxiii.

9 One manifestation of this was the Japanese-American conflict over a lack of increase in imports from the United States. With a trade war in the offing the dispute was deall with at the highest level of politicians involving a trade summit between President Bill Clinton and the Japanese Prime Minister Morohiro Osokawa. See: Woollacott, Martin. Tussle over trade will leave the giants with sore heads. p. 20. 
Shift in political practice : In addition to this shift of revevance in public perception, traditional means of conducting foreign policies lost their rational feasibility or impact. Numerous examples can be drawn: the reluctance of the west to engage in the war in Yugoslavia, caused by doubts over its expediency and rationality, the lack of effect of the démarches and the issuing of diplomatic disapproval for the putsch in Haiti' ${ }^{10}$, and the general reluctance to break- off diplomatic relations as a sign of disapproval". Consequently foreign policies today are increasingly conducted with less spectacular and more efficient instruments, for example tariff policies, economic sanctions or financial offers ${ }^{12}$. Both spheres of policies developed into each other's instruments ${ }^{13}$.

The next binary distinction which is on the wane is the logic of "international relations" versus "transnational policies". This distinction has been undermined by three interrelated features of European and global politics :

EC-integration and the domestic/foreign policy overlap : Nearly four decades of increasing economic integration increased the jurisdiction of the EC to a degree, that gave the de iure internal policies of the EC, rather than the policies of the Member States, an undeniable impact on third countries ${ }^{14}$. The Common Agricultural Policy (CAP), the EC's Research and Development Programmes and the Single Market Programme had enormous repercussions for the global economy as had the three rounds of enlargement ${ }^{15}$. A parallel development of globalisation induced by quantum

10 Nearly three years after the official disapproval and the claims to restore democracy by the USA, the Organisation of American States and the EC/Twelve, the situation is largely as before. See: Toussaint, Ernst. Die Amerikaner sind am Zug. p. 8.

11 This is a logical development in a world in which societies interact to an extent which renders it simply impossible for the corresponding political entities to stop talking to each other. The efficacy of the dialogue, however, is contingent upon having something more substantial to offer or withdraw than "approval".

12 Even the US government, one of the strongholds of traditional foreign policy, resonts to new methods. Concerning Haiti the United States had offered the military rulers $\$ 50$ million to agree to restore democracy. See: Chamberlain, Greg. US offers Haiti amy $\$ 50 \mathrm{~m}$ to restore democracy. p. 9.

13 In March 1994 the United States attempted to force China to concessions concerning human rights issues like the oppression of political dissidents before they would renew the country's Most Favoured Nation trading status.

The loss of MFN was supposed to have devastating effect on China's balance of payments. See: Long, Simon. Christopher to focus on human rights. p. 15. In a similar vein the United Kingdom considered but then ruled out a trade war against Malaysia as relatiation against the allegations in the Pergau dam affair. See: Beavis, Simon/Cowe, Roger/Buckingham, Lisa. Gatt rules stop British retaliation. p. 5.

14 See: Wannamethee, Phan. The Importance of the EC for South-East Asia: The ASEAN Perspoctive. passim.

15 The EU now encompasses a market of some 370 million people. As of 1994 the European Economic Area has extended the reach of the EU's internal economic policies so that it virtually accounts for and influences $40 \%$ of the world trade. See: Stopford, John M. European Mutinationals' Competitiveness: implications for trade policy. p. 52. 
leaps in technology brought an ever-increasing acceleration of global communication by transportation and media systems ${ }^{16}$.

The increased global exchange of goods, services and persons - all subject of legislation and thus political decision - has prompted the perception of an everincreasing foreign/domestic policy overlap - of a transnationalisation rather than an internationalisation of policies.

Increased Dynamism : The same phenomenon of communicative interaction creating the perception of immediate corcern can be seen in the process of replacing the passive and static notion of "relations" with the more dynamic notion of "policies". Pictures of Kurdish refugees broadcast from Iraq or Muslims fleeing from Bosnia led western governments to active policies, which unlike relations (describing the realm between two 'sacred' entities) intrude into a state".

\section{Finally the logic of foreign versus external has also been undermined:}

The increased knowledge about and the familiarity with phenomena originating outside one's own society and nation is making way for a more sober assessment of "the foreign" and a "foreign" policy as opposed to an "external"1. Foreign policy in the past relied on a "consequent misunderstanding", which is the perception, that a largely homogenous entity, called a nation or a state, had to deal with largely different entities: the others ${ }^{19}$. This otherness was the basis of the legitimate foreign policy. Yet nowadays "the outside/inside distinction... becomes at least difficult to maintain... in a world of virtually instant global communication... ${ }^{20}$. Posing problems for the nation state, this point is also crucial for the EU. In fact this problem adds to a special characteristic of the EU: the lack of definition of the European identity ${ }^{21}$.

16 For an in-depth discussion of the political, sociopsychological and cultural implications of the concept of globalization, see: Featherstone, Michael (ed.). Global Culture. Nationalism, Globalization and Modemily. passim.

17 In both cases public opinion or better publicised opinion was a major factor for adopling active stances to internal crises of other states. See: Mayall, James. Non-intervention, Self-determination and the 'New Wortd Order'. p. 425.

18 The basic innovation was the questioning if there is a distinction at all. The whole development of post-structuralist and post-modemist approaches in the IR theory is a case in point. Post-structuralistm intends to deconstruct and reconstruct the old paradigms. Although much criticised for being merely destructuve, the application of these approaches leads to new insights into the socio-psychological conditions of "foreign" policy. See for example: Walker, R.B.J. Security, Sovereignty and the Challenge of World Politics. passim. and Campbell, David. Writing Security. passim.

19 With the prevailing assumption that a homogenous self exists, a nation state is able to draw on a selfinterest as the legitimate basis of the 'national interest'. For attempts to clarify the concept of the national interest see: Ifestos, Panayiotis. op. cit. p. $96 \mathrm{ff}$.

20 Beyer, Peter F. Privatization and the Public Influence of Religion in Global Sociely. p. 384.

21 Commission of the European Communities. Europe and the Challenge of Enlargement. p. 11. 
It can be held that the EC/EU will always lack the characteristics to formulate a policy towards "genuine foreigners", because the continuing uncertainty about the European identity will prevent Europe from the "boundary-producing-performance", which implies a coherent picture of the internality of a state $e^{2}$.

Even if the European integration process succeeded in shitting the reference points for political identity from the national to the supranational level, the sociocultural connotations of the term "4oreigner" would be unlikely to shift swiftly with it. The identity of the European nation states and their perception of the foreign have a historical basis stretching back over many centuries. A similar development in the EU would necessitate a similar period of time. Yet every enlargement of the Union perpetuates the uncertainty about the EU's internality and thus about what a genuinely "foreign" policy can possibly be. The concepts of the foreign of both nation states and the EU loose in the race against global and European integration.

The points made above combine to form the process of notional restructuring. While this multidimensional process is as yet unfinished, it can be submitted that the mysticism prolonged by so many governments for the purpose of protecting the illusion of sovereignty, is increasingly perceived as devoid of substance.

The factual restructuring : Because of the increased objective and perceived external impact of the EC, third actors have sought increased representation in Brussels in order to defend their interests and achieve good working contacts with the $\mathrm{EC}^{23}$. In addition to the process of notional restructuring, already outlined, this interest in "good contacts" also helped to transform the relations of the EC from pure consultations concerning economic policies into relations of a quality which was formerly only conceivable for states. This has led to about 160 permanent missions being registered in Brussels which keep regular contact with the EC institutions just like embassies to nations states. The 'normative power of the factual' helped enhancing the notional restructuring.

To the extent that the two processes continue, the distinctions in these three dimensions are becoming less and less meaningful. Hence a strict institutional separation has become more and more problematic.

\section{Chapter 2. Circumventing the Gordian Knot}

\section{2. a. The constitutional structure of the TEU : relations in the "temple"}

The IGC on European Political Union of 1990/91 was seen especially by the French and German governments as the indispensable complement to the IGC on

22 Ashley, Richard K. Foreign Policy as Political Performance. p. 51. (Ciled after: Campbell, David. Writing Securily. p. 69.)

23 See: Ahein, Eberhardt. The Community's Extemal Reach. p. 31. 
Monetary Union. It attempted to harmonise the political structure of the EC and to close the gap which the EPC-EC construction has still left open between foreign policy and foreign economic policy in both formulation and implementation. The TEU, however, shows evidence of being tinkered with in the negotiations. It is piecemeal and not sufficient as a solid constitutional basis for a politically stable Union ${ }^{24}$. Despite its impressive name, the TEU does not incorporate all the new policy-sectors into one unified political structure. Instead it introduced two separate pillars, the CFSP and the Justice and Home Affairs (JHA), which are not communautarian. Far from being only an aesthetic question, this structure creates an instability in the Treaties and will make the EU difficult to operate. It impinges directly on the international 'actorness' of the EU because the status of the Union and the changes in the international system make a functionally separate conduct of the policy-fields at best inefficient and at worst ineffective. While the foreign economic policy (EC pillar) directly influences the "genuine" foreign relations of the EU (CFSP), both in turn can directly influence and be influenced by the formulation and execution of internal policies under JHA. The formulation of immigration policies towards Eastern Europe (a JHAmatter under Art. K.1. TEU) for instance is closely entangled with the general perspective of foreign policy developed under CFSP and the aid and re-conversion programmes developed and managed by the $\mathrm{EC}^{25}$. The artificial procedural separation under the "temple"-structure of the TEU thus does not equip the EU with a holistic and encompassing approach to the world. It prevents the polity from managing the complex interdependence of the different policy-fields and from accommodating the often conflicting goals.

The TEU incorporating the Rome Treaty assigns different decision-making procedures to different policy-sectors, some of which straddle two pillars. It is symptomatic that for example a common visa-policy is a matter of the EC pilla ${ }^{26}$ whereas adjacent policy-fields, like regulations for the crossing of the Union's borders, are a

24 The Trealies establishing the European Communily and now the Union are international treaties. It took a long time until it was legally established, that they amounted to something resembling a constitution. Meanwhile several ECJ rulings and the reforms of the TEU leave little room for doubt. This in tum provides the political scientist with a tool for measuring the performance of the Treaties. Every criticism of its legitimacy, coherence and operationability, - as well the present one - uses the characteristics of a constitution as a yardstick. Indeed every enquiry has to do so: If the political scientist intends to analyse a political actor, which although it is not a state has adopted undeniably state-like qualities, it exerts power which in the western tradition of the rule of law has to be legitimised and limited by a constitution. From an analytic and normative point of view it is thus indispensable to regard the European Treaties as such.

25 On a national level the pressing issue of immigration has already influenced the way in which national governments perceive and deal with such diverse problems as foreign economic policy, immigration policy, social policy and securily. Seө: Baldwin-Edwards, Martin/Schain, Martin A. The Politics of Immigration. p. 1.

26 Art. $100 \mathrm{c}$ EC. 
matter for JHA. In contrast to the EC pillar, which is characterised by a high degree of supranational policy-formulation, the dominant feature of the new pillars is intergovernmentalism. This has consequences for the constitutional quality of the EU visà-vis the Member States and in international relations. The principal question is if the EU like the EC has a legal personality. Only this legitimises the exertion of autonomous powers.

Unlike the Treaty of Rome, the TEU does not explicitly assign a legal personality to the Union ${ }^{27}$. This has led to the judgement that it does not possess any "legal personality or standing as such under international law $w^{\text {m28 }}$. On the other hand, this personality could be inferred indirectly from Article B TEU, which states that one of the Union's aims is "to assert its identity on the international scene" and which introduces" a citizenship of the Union". Neither aim can be conceived without the concept of legal personality in the background. Nevertheless it is striking that the concept has not been made constitutionally explicit. This is further evidence of the haste and incoherence with which the Treaties have been changed and it creates fundamental problems for the Union's external 'actorness' per se ${ }^{2 \theta}$.

Internally, it creates the question whether the EU, like the EC, creates new exclusive policy fields. Having been a legally contested issue over the decades in the EC pillar, it was politically never finally resolved. Due to the reluctance of the Commission to engage in a struggle with the Council, the legislation of the ECJ on the issue is only very limited ${ }^{30}$. Instead all actors preferred to circumvent the issue.

Here I will emphasise the consequences of this insecurity for the EC's political 'actorness'.

Prior to the TEU the increasing integration of aspects of foreign policy under the EC decision-making structure has encountered legal doubts as to what were the limits of the EC's external competences. Whereas the more restricted concept of ex-

27 Compare with Art. 210 and Art. 211 of the Treaty of Rome.

28 Curtin, Deirdre. op. cit. p. 27.

29 As Curtin argues, it has to be acknowledged that the thrust towards Political Union was a sudden one and the concept not as well prepared by the IGCs as the concept of the EMU. (Curtin, Deirdre. op. cit. p. 17.) Yet the lack of slable concepts for the IGC was mainly the result of dogmatically ignoring the substantial amount of proposals crealed by the EP over the years, for example its Draft Treaty on European Union: OJ C 077 19/3/1984 in conjunction with OJ C 277 $17 / 10 / 1983$.

30 Only three examples of the rare species have been issued: Opinion $1 / 78$ of the court of 4 October 1979. (Subject: International agreement on natural rubber.) In: Reports of cases 1979. pp. 2871-2921.; Opinion 1-76 of the court of 26 Aprul 1977. (Subject: Draft agreement establishing a european laying-up fund for inland waterway vessels.) In: Reports of cases 1977. pp. 0741-0762.; and: Opinion 1-75 of the court of 11 November 1975. In: Reports of cases 1975. pp. 1355-1365. 
clusivity (in the narrower sense) is constituted by EC primary law", the wider concept of pre-emption encompasses all fields upon which the EC has legislated or upon which further legislation by the Member States could alter the scope of EC legislation or create doubts about its source and effects ${ }^{32}$. In fact substantial discrepancies remained between the EC and the Member States - and thus internally between the Commission and the Council - about the limits of the EC's competence when it takes action in the foreign/external field. Let us explore the consequent difficulties examining international agreements.

In the case of international agreements the relevant provisions, Art. 113 EC for the commercial policy, Art. 228 EC for agreements with Third countries, Art. 238 EC for association agreements and Art. $235 \mathrm{EC}$, the regulation for taking "appropriate measures" to attain "one of the objectives of the EC and the Treaty" were in desperate need of clarification by judicial review. Yet for political reasons the Commission and the Member States have often agreed to conduct a mixed action. A multitude of so called "Mixed Agreements" were concluded by making the Member States parties to an agreement jointly with the EC. One case in point is Art. $113 \mathrm{EC}$ which empowers the EC to act in the field of external commercial policies. However, quite obviously contrary to the idea, the enumerated policy-sectors in this article have been interpreted by the Council as an explicit enumeration of competences rather than as examples or emphasis ${ }^{33}$.

As a consequence the Council has usually decided that agreements with Third states or organisations were in need of a "mixed" characteristic, when they covered areas which were not explicitly mentioned in Art. 113 EC. Although the Commission was frequently of a different opinion it rarely took legal action before the European Court of Justice (ECJ) $)^{34}$. Usually, it wilfully negotiated the so called "Mixed Agreements" jointly with the Member States ${ }^{35}$. The conclusion of Mixed Agreements is thus

31 European lawyers define the Treaties establishing the three European Communities, the Single European Act and the Treaty on European Union as 'primary law', European law which emmanated from the exercise of law-making power by the institutions established by the "primary law' is called 'secondary law'.

32 Neuwahl, Nanette A. op. cit. p. 722.

33 The former interprelation leads to a strong limitation of the compelences of the EC, the latter would allow its expansion.

34 One of the rare cases of action was the Case 217/86. The Commission has taken legal action against the Council before the ECJ concerning the autonomous exercise of the Community's competences without the Member States on the International Labour Conference. Yet it was later withdrawn by the Commission upon having reached a political compromise with the Council. See: Case 217/86; OC J 242/86 p. 7. 26/9/86.

35 The characteristic of "mixety" was for example employed in conclusion of the international coffee agreement (OJ L 308/83 of 9 November 1983), in the economic cooperation agreament with the ASEAN countries (OJ L 144/80 of 10 June 1980) and concluding the convention on biodiversity (OJ L 309 of 13 December 1993). 
more often than not the result of a lack of clarity as regards the question if the EC has the exclusive competence to $\mathrm{act}^{36}$.

By their participation as separate parties in international agreements, the Member States retained a high degree of autonomy and limited the autonomous action of the EC. Procedurally it required them to reach unanimity concerning the policycontents of the agreements and subsequent changes, where otherwise a majority in the Council would have been sufficient ${ }^{37}$. This practice unduly tied the hands of the $E C$, often where it would not have been constitutionally necessary.

In deviating opinion from the 'explicists' in the legal theory, the parallelismtheorists establish a right of the EC to become externally active in all fields which have been recognised as EC competence internally. Indeed in its Opinion 1/76 [1977] the ECJ has implicitly confirmed the theory of parallel EC competences. Conforming to this interpretation would widen the scope of the EC's autonomous external action of the EC substantially and would be likely to introduce a dynamic element into the EC foreign/external policy process. This is because recent changes have moved more policy-fields to the EC level. Not only have treaty changes in the SEA and the TEU increased the scope and level of EC competences but in addition the European Council has given way to the pursuit of so called "interrelated objectives" ${ }^{m 8}$. This element - resembling constant judicial review - was supplemented by the activities of the EJC, which has continuously exerted a centralising influence ${ }^{39}$.

It is significant indeed that the SEA as well as the TEU have avoided making explicit the EC's range of foreign/external competences. To put it differently, they have avoided making explicit once and for all what is beyond the nation state. Once again an incremental and thus constitutionally ambiguous path has been pursued. In practice, however, it cannot be the case that the EC wields the exclusive competence to regulate a policy field internally and not the corresponding competences when third actors are interested in negotiating on the same matter. The lack of clarity concerning the external competence of the EC pillar inherited from past practice is further bedevilled by the TEU. On the one hand, Article M TEU gave the guarantee that "nothing in this Treaty shall affect the Treaties establishing the European Communities." On the other hand, Article C TEU stipulates that the Union shall "ensure the consistency of its external activities as a whole in the context of its external relations, security, economic and development policies." Thus establishing a constitu-

36 Neuwahl, Nanette A. op. cit. p. 718.

37 Ibid. p. 739 .

38 Lodge, Juliet. Toward the European Political Community. EEC Summits and European integration. pp. 629 and 640.

39 Mancini, G. Federico. The Making of a Constitution for Europe. passim. 
tional and institutional tension, it is remains unclear to what extent the EC pillar still has external relations of its own and can care autonomously of its external business.

It must be expected that not only the Council but as well the Member States can strangle the Union's autonomous development and keep it under close intergovernmental control. What makes matters worse is that nothing can be rectified by the ECJ because this institution is explicitly excluded from making judgements about the EU structure and creating clarity ${ }^{40}$. It can lend no hand at all in defining the existence of exclusive competences in the narrower sense ${ }^{41}$. As a result no actor can be certain of the scope and level of competences under the jurisdiction of the EU. Moreover since the range of the pre-emptive competence of the EU cannot be established judicially, nobody can predict the stability of the EU's action, after policyfields have been elevated to the EU level. It is likely that the vested interests of the Member States will not allow for the necessary quantum leap.

The internal caveats to be expected by the political actors exploiting the constitutional uncertainty would lead to a situation where the legally and politically unfortunate practice of "Mixed Agreements" would be continued. The contractual partners involved would vary according to the legal interpretation. It would be sometimes the EC only, sometimes the EU only, sometimes both actors in a new form of Mixed Agreement, the old form of a Mixed Agreement with the EC and the Member States and if need be maybe even a form which would involve the EU, the EC and the Member States. At worst the EU could be declared importent for concluding international agreements and would have to fall back on the actions by the EC under Art. $228 \mathrm{EC}$ and 228a EC or by the Twelve Member States ${ }^{42}$. This scenario may have even been effected deliberately by neglecting the issue in the TEU altogether. The inability to conclude international agreements as a contractual partner in its own right, however, would deprive the TEU from the most tangible sign of non-military exercise of foreign policy and would settle its international 'actorness' near zero.

The perpetuation of the artificial distinction in the TEU is a direct result of the divergent conceptions of the two fields in the minds of the national political elites. After having finally admitted that the whole scope of foreign policy fields falls within the competence of the Union ${ }^{43}$, the question of the level of political competence within these fields is still unclear and a major obstacle for bstaclethe achievement of a genuinely European foreign policy. 41 For an explanation of the legal sense of the concept and an insight into the political consequences
see: Neuwahl, Nanette A. Joint Participation in Intemational Treaties and The Exencise of Power by The EEC and its Member States: Mixed Agreements. pp. 717-725.

Curtin, Deirdre. op. cit. p. 27. 
At the IGC on Political Union the Commission made a distinction between and recommended a common instead of a single foreign policy ${ }^{44}$, because it was seen as unrealistic that one exclusive foreign/external policy could substitute the diverging foreign and security policies of twelve or more nations in the international system. Although it can be argued that the EPC process has resulted in a convergence of the national inputs into the international system, the Twelve's foreign policies still differ in four important respects ${ }^{45}$ :

1. in their approach to foreign policy per se, which involves the question of power or civilian politics

2. in their perception of the relevance of different regions, countries and political developments there

3. in their perception of foreign economic interests

4. in their perception of security threats ${ }^{46}$

Having acknowledged this and having transferred the distinction between single and common policies into the CFSP pillar of the TEU, however, means having accepted in principle a leeway, which the Member States have from any average common foreign policy formulation. Seen on a continuum between national control over foreign policy on the one hand and complete and exclusive control by the Union on the other hand, the CFSP does not clarify the precise position between these polar extremes. This is the source for much incalculability of the EU's behaviour especially in times of crisis. Furthermore it is likely that the common foreign policy practice collides with the single external policy conduct. This installed competition finds its expression in the institutional and procedural separation of the essentially intertwined fields.

From a Third actor's perspective the uncertainty of policy-scope for each pillar, resulting from the fragility of the constitutional sub-structure and the uncertainty of policy-level, resulting from the sketched common versus single dilemma turns into an uncertainty of actor when a policy-field has to be dealt with by the Europeans. This

44 Commission of the European Communities. Political Union. p. 13.

45 These differences are the result of several faclors, whose impact can not be easily neutralised. For an encompassing in depth-analysis of the Twelves' foreign policy behaviour within the EPC see: Hill, Christopher (ed.). National Foreign Policies and European Political Cooperation. passim.

46 Although the EU at present does not engage on the field of military security in a dimension which is worth mentioning, the perception of a security threal does not necessarily entail the handling of which with the instrument of military action. Since the answer to such a threat can lie in the fields under discussion in this dissertation, the inclusion of the point completes the piclure. 
gives room for serious doubts if the Union will be accepted by all international actors to the same extent that the EC was accepted, if after some decades ${ }^{47}$.

And indeed the reluctance of Third actors to engage into agreements with the EU would be understandable. In combination with the fundamentally district decisionmaking structures in the EC and the CFSP pillar, the uncertainty of actor mutates into an uncertainty of process.

\section{B. The Uncertainty of the EU's Process}

The control over CFSP is allocated to the intergovernmental institutions of the Union - the Council of Ministers and the European Council - and decisions must be taken unanimously, except when a joint action is taken. Even then the Member States can decide unanimously about what decisions should be made with Qualified Majority Voting (QMV)

In what looks like a late and symbolic good-will statement, the negotiators attached "Declaration No. 28 on Voting in the Field of the Common Foreign and Security Policy." to the Final Act of the TEU. It states:

"The Conference agrees that, with regard to Council decisions requiring unanimity, Member States will, to the extent possible, avoid preventing a unanimous decision where a qualified majority exists in favour of that decision."

While it is politically understandable what the negotiators wanted to achieve with this declaration, it is - to put it mildly - hard to imagine what constitutional lawyers would make out of it in the case of an institutional quarrel about CFSP-related voting in the Council. The position and status of the declaration in the Treaty does not allow an impact as a counterweight to the unanimity provisions. The negotiators succeeded, however, in creating not only a bewilderment of any analyst but also an uncertainty of process even within the CFSP pillar.

In comparison with the dynamism which the policy-formulation process in the EC has shown, the provisions for the Council in CFSP can be expected to slow down the process substantially. In this highly contested policy-field, where questions of sovereignty and national pride are at stake, the de facto veto allows the Member States to retain the principal competence for foreign policy and determine if subjects are of a "general interest" so as to deal with them in the CFSP framework. Here the scope for horse-trading to reach an agreement is extraordinarily limited, and the ar-

47 Compare: Lachmann, Per. International Legal Personality of the EC: Capacity and Competence. passim.

48 Art. J.3.2. and Art. J.8.2. TEU. 
rangement is likely to prove even less conducive to settlements than the unanimity years of the EEC. It is exacerbated by the loss of the sole right of initiative and withdrawal on the port of the Commission and thus the element with which the Commission often managed to make up for its lack of voting-power in the Council.

Since the whole structure of the CFSP is designed to rely on an incremental development of the foreign policy competence ${ }^{40}$ rather than assigning clear general competences a priori, this is bound to keep the EU's jurisdiction over the field in check. A fast development of a reliable, stable and binding acquis politique is thus rendered completely illusory. Without such a body of foreign policy orientations the Union will be unable to arrive at reliable basic common standards for its actions on the international scene let alone to define the fundamental interests of the Union ${ }^{50}$. This strangling of the CFSP and the probable freezing of the acquis politique will contrast sharply with the external effects of the EC's competences (explicitly or implicitly international). These effects are already significant and can be expected to intensify with increased economic integration and economic policy integration ${ }^{51}$.

Distinctively different is the relative importance which the Presidency and the Commission have in the two pillars. Compared to the EC pillar, the Presidency under CFSP has a far bigger role. As the Commission is not the sole proposer of foreign policy actions but also every Member State, the leading role of the Commission is considerably curtailed. This in conjunction with the absence of Qualified Majority Voting will lead to a much more rigid intergovernmental process. As a result the Presidency's functions as initiator, mediator or honest-broker in the attempt to produce decisions is substantially more pronounced and the Commission is largely confined to a supportive role.

The consequence is a far higher discontinuity and volatility of the CFSP. This is because the domestic politics of the Member States influences their issue-related positioning on the European political stage ${ }^{52}$, and secondly, because the different sixmonth Presidencies have different expectations, goals and strategies concerning foreign policy issues ${ }^{53}$. Even if the differences are not fundamental, it has to be born in

49 Holland, Martin. European Community Integration. pp. 124-125.

50 Art. J.1.2. TEU.

51 Even if the plan of the European Monetary Union failed, the incremantal expansion of the EC's jurisdiction would be unlikely to cease. With the exogenous factor of a global regionalisation development and the endogenous evolution of the EC by including new policy fields in the Maastricht Treaty and the expansion of the qualified majority voting in the Council a continued thrust to integration can be expected.

52 Bulmer, Simon. Domestic Politics and European Community Policy-Making. passim.

53 Pederson, Thomas. The European Union and the EFTA Countries: Enlargement and Integration. p. 172. 
mind that in particular the foreign policy field is strongly characterised by declarations, resolutions and rhetoric. Hence, depending on the circumstances, a difference in the style of foreign policy conduct can have an immense impact. The resulting discontinuity due to the rotation is only partly mediated by the Troika system ${ }^{54}$. As a result every six months the "genuinely political" aspects of the EU's international actions can change, while the Commission - the main institution responsible for the foreign economic policy dimension - struggles to steer a stable course.

The European Parliament (EP) has gained substantial competences under the EC procedures covering internal policy-fields: the majority of policy-fields is now subject to the assent, co-decision and co-operation procedures ${ }^{55}$. This stands in sharp contrast to the CFSP. Here the EP's competences can honestly be described as minimal. As with JHA, the EP has to be heard, has a right of being informed regularly and of directing questions or issuing recommendations (Art. J.7. TEU). But it lacks the influence to shape foreign policy ${ }^{56}$. The circumvention of the EP as a major actor in the foreign policy field does not come as a surprise. Let us consider here the relevant EC provisions for external agreements, where only a few examples of the EP's participation can be found:

Whereas for the constitutionally special Association Agreements the EP hs to give its assent (Art. 228.3. EC.), only the consultation procedure is foreseen for normal agreements with Third actors (Art. 228.1 EC.), except for those "establishing a specific institutional framework by organising co-operation procedures, agreements having important budgetary implications for the Community and agreements entailing an amendment of an act adopted under the procedure referred to in Art. 1896". These three exceptions need the EP's assent. Concerning the last exception a special distinction can be found. Art. 238.3. phrase 1 EC confines the EP to the consultation procedure when regulations in an agreement concern fields for which an internal legislative procedure would require the co-decision procedure of non-existing domestic legislation. This distinction reduces the capacity of the EP on the external front substantially. Yet, excluding the EP from contractual agreements with specific regulations whose transfer into EC law needs the co-decision procedure and thus the assent of the EP, poses the danger of an unreliability of the EC/EU for third actors, due to the fact that the EP could demand substantial changes or even block the transier to internal legislation altogether. Finally in the conduct of the commercial policy (Art. $113 \mathrm{EC}$ ), economic sanctions (Art. 228a EC) and the emergency procedure

54 The Troika of the EU is the combination of the preceeding, the current and the succeding Presidency. It is a formula of the EU's international representation and has functions in the EU's internal organisation also. Art. J.5. TEU.

55 Jakobs, Francis/Corbett, RichardShackleton, Michael. The European Parliament. pp. 203-205.

56 All these rights had been agreed to already in the regulations governing EPC. The impact was minimal. See: Nuttall, Simon. The Institutional Network and the Instruments of Action. pp. 57-59. 
(Art. $115 \mathrm{EC}$ ) which can empower the Community to take external action, the EP is left out completely.

The examination has shown that the EP's powers concerning the formulation of foreign/external policies in both pillars are heavily curtailed. Although this does not present a problem in itself, it does if we bear in mind the developed concept of the domestic/foreign policy overlap. Thus the EP wields influence on internal policies with external effects but is deprived of effective influence on the foreign policies of the Union. This holds true not only for the entering into agreements but also for all facets of CFSP.

However, the EP's aspirations to obtain more influence on the decisions made in the sphere of foreign policy should be supported for essentially two reasons. First, the democratic legitimation of decisions in both new pillars is extremely weak ${ }^{57}$. An en détail scrutiny of foreign policy actions, like the examination of treaties, an involvement into the foreign policy processes and the ratification of broad guidelines by the EP is thus desirable from a liberal-democratic point of view. Second - and in the context of this analysis more important - the EP could provide an additional connection between the two pillars, helping to co-ordinate the two intertwined sides of the same foreign policy coin with the aim to make policies work better. Further proposals, for instance to involve the EP directly in negotiations, however, have to be rejected for the sake of precisely this end. Not only would they blur the distinction between executive and legislative - the precise fact, which the EP wants to do away with on the side of the Council. It would also hamper the EU's 'actorness' by making the process unnecessarily complicated and cumbersome.

We have already noted that the TEU has installed a common instead of a single foreign policy under CFSP whereas the EC pursues its foreign economic policy as a "single economic and political entity" . Thus the TEU has created a considerable difference between the two pillars concerning the stability and validity of the foreign policy decisions in the EU's territorial and political realm. Even if the Council under CFSP decides unanimously, that the adoption of a common position is necessary, the Member States ensure, that their own positions harmonise with the common position defined in the Council ${ }^{50}$. In the event of major differences nobody can guarantee even the slightest communality in the stances of the Member States "harmonised" under CFSP ${ }^{\infty}$. The same is true in essence for the joint actions of the Un-

57 Lodge, Juliet. Transparency and Democratic Legitimacy. pp. 2 and 15.

58 Simmonds, K.R. The Evolution of the Extemal Relations Law of the European Economic Community. p. 645.

59 Art. J.2.2. TEU.

60 As the Greece-EU controversy over such an essential subject as the stability on the Balkan shows. See: Thumann, Michael. Streit um die Sonne. p. 4. 
ion. The applicability of the escape clauses, Articles J.3.6. and J.3.7. TEU cannot be sufficiently controlled by a constitutional court. The durability and reliability of the structure is still contingent upon the Member States' willingness to sustain long-term strategies and to compromise on this field.

These constitutional difficulties do not exist in the case of a parallel EC action. While the Treaty provisions directly bind the Member States not with broad catchphrases but en détail to enforce the Community measures, the Commission acts as the guardian of the Treaties and can take recourse to legal action in the event of an infringement of EC first and secondary law ${ }^{61}$. Moreover, the TEU has strengthened the power of the ECJ to enforce its sentences ${ }^{62}$.

The different nature of the two decision-formulation processes in combination with consitutional stumbling blocs will undoubtedly create substantial differences in the outputs and make coherence run into sands. Four scenarios of incompatibility can be identified:

1. that the EU, acting under EC laws, can take a decision on the 'economic' sides of an issue while it is impossible to reach a common position on the 'political' side.

2. that both outcomes are not and do not take account of each others impact.

3. that there is an incompatibility of the objectives being pursued with the two different policies.

4. that there is a different impact of due to a lack of fine-tuning of the two external policy fields.

The likelihood of one of the above options becoming a reality is increased by the inability of the CFSP structure to control the Member States.

A process error of the first kind emerged with the war in Chechnia and the lack of a coherent position of the EU ${ }^{\circledast}$. Due to the unanimity provision in the CFSPCouncil, the EU per se was incapable of adopting a clear position in the foreign policy field. Too divergent were the views of the UK, France and Germany. As a consequence it has fallen again on the Member States to express their foreign policy preferences via diplomacy. By contrast the European Parliament took position immediately and together with the Commission agreed on action. They delayed the rat-

61 Ludiov, Peter. The European Commission. pp. 104-105.

62 Compare Art. 171 EEC with the new Art. 171 EC, providing for the ECJ's power to impose lump sums or penalties on states infringing $E C$ law.

63 The internal conflict within the Russian Federation involved the desire of the Chechenian Republic to seceed from Russia. 
ification process of the EU-Russia Interim Agreement covering trade provisions of the partnership agreement. In addition, humanitarian aid was provided by the Commission from the EU budget ${ }^{64}$.

\section{Chapter 3. Attempts at Bridging the Procedural Gap: coherence by interaction}

In order to remedy the inconsistency that the IGC has created with the weak constitutional structure, notably by the lack of a really unified decision-making centre, the institutions themselves have been forced to install interlinkages for the fulfilment of the Treaty aims, acting within the narrow limits of the TEU arrangement. They cope with this demand with differing success.

A measure which could prove stabilising and coherence-fostering is the incorporation of the former EPC-Secretariat into the Council. With becoming an integral part of the Council structure, the CFSP could benefit from the relationship which has evolved between the Council Secretariat and the General Secretariat of the Commission. In the past both administrative units have strengthened to the interinstitutional processes; so much that the stable relation between the Secretary General of the Commission and the Council Secretary is considered one of the most important elements for a fruitful co-operation between the two major bodies of the EU⿱丷${ }^{\text {es }}$.

The evolving characteristics of the CFSP section of the Council secretariat are contingent upon the dispersion of functions between the Secretariat itself, COREPER and the Political Committee; a relationship still to be sorted out. Past experience, however, suggests that the section will not develop a political life of its own. The relevant officials in the Council Secretariat normally serve for only a few years in Brussels and then return to their national administrations. A supranationalisation resulting from a shift of loyalth by the civil servants towards the Council per se instead of a loyalty to the governments of the Member States will therefore be easy to prevent ${ }^{66}$. The Council Secretariat despite all its bureaucratic merits was deliberately conceived as an administrative tool providing a memory-function and thus compensating for the lack of continuity which is a product of the Presidency change ${ }^{67}$. It cannot substitute a close interaction on the level of policy formulation.

64 See: The Week in Europe. UK Commission publication. 12 January 1995 and 9 February 1995.

65 Ludlov, Peter. The European Commission. pp. 114-115.

66 Source: Interview with Council Official responsibie for the organisation of the CFSP under Council auspices (22/7/1994).

67 Nuttall, Simon. European Political Co-operation. p. 21. 
Designed to determine the general political aims of the Union (Art. D. TEU) it could indeed be assumed that the European Council will act sufficiently as "guideline producer" in order to ensure the coherence of the two pillars in their foreign policies.

Before the extraordinary events during 1989-1991 there had been only two occasions where the European Council had discussed EPC matters. (The European Council in Venice, June 1980 and The Hague June 1986) ${ }^{68}$. Much as the function of coherence-provider was already conferred upon it by the Solemn Declaration on European Union ${ }^{60}$, not once has the European Council shown inclination to take on this task in order to increase the EC/EPC's coherence ${ }^{70}$. The EC pillar by contrast has in the past experienced substantial direct involvement with the European Council exerting a positive influence to break deadlocks and to overcome procedural obstacles $^{n \text {. }}$.

Only two European Council meetings have so far taken place since the coming into force of the TEU in November 1993. As the Corfu Council (24-25 June 1994) has been primarily concerned with the choice of the new Commission president, it could not provide empirical evidence to test the argument. By contrast the Essen European Council (9-10 December 1994) emphasising the strategies of rapprochement of the then six Eastern European Associates, indeed stressed matters of external relations of the EU to a remarkable extent. It could be submitted, however, that this was more an internal matter than an example of foreign affairs, as it corcerns the enlargement of the EU.

The declaration of the Essen Council was further concerned with the situation in the Mediterranean and plans of the Commission and the Council to increase economic co-operation as a means of preserving political stability in the region. As this is a matter which falls neatly into the grey area of EC external policy and foreign affairs, it is particularly striking that the Council's declaration does not mention the CFSP-mechanisms at all ${ }^{72}$. This matches past experience and indicates that the European Council cannot be expected to act conducive to a strong deepening of the foreign policy field.

68 Bulletin of the European Communities 6/1980. pp. 7-11. and Bulletin of the European Communities 6/1986. pp. 7-12.

69 Signed by heads of state and govemment in Stuttgart the 19 June 1983. See: Bulletin of the European Communities 6-1983. p. 25.

70 Compare: Solemn Declaration on European Union. p. 25. and Nuttall, Simon. Interaction between European Political Co-operation and the European Community. p. 215.

71 Lodge, Juliet. Toward the European Political Community. EEC Summits and European Integration. pp. 648-649.

72 Essen Summil Declaration. Reprinted in. Agence Europe 11/12/94. 
This example underlines the failure to ensure coherence at the top of the political structure. We must, hovwever, be mindful of the fact that the really decisive battle for coherence is fought in the day-to-day business. Cohesive institutional interaction, indispensable for en detail fine-tuning of policies, can by no means be substituted by a highly general guideline production.

In this respect past experience can once more serve as Cassandra for the future capacities of the Council. The fact that the same persons which were in the General Affairs Council of the EC dealt with matters of the EPC and the participation of the Commission in the EPC brought only minor improvements with regard to Europe's coherence. The reason lies with the 'double contamination fear' which proved a stumble block for the full range and capacities of the EC to be used in implementing EPC decisions. Some countries like France and Denmark were hostile to this because of fear of a supranationalisation of the foreign policy field while other countries, like the Netherlands, had a phobia against alleged attempts to render the EC procedures intergovernmental. Hence the two camps tried to keep the procedures of the two organisations distinct for essentially different reasons. It is this motive that can be found in the TEU provision which continues the EC-CFSP separation by explicitly stipulating that "nothing in this Act shall affect the Treaties establishing the European Communities or any subsequent Treaties and Acts modifying or supplementing them ${ }^{\text {n?3 }}$.

The Commission also has to take its share of responsibility for the constitutional struggle between intergovernmentalists and supranationalists. The Commission as executive of the EC was rarely willing to be used as an instrument in the hands of the foreign ministers. In the past it conducted its own external relations with sometimes considerable foreign policy implications quite independently and without asking for authorisation by the EPC ${ }^{74}$, mainly because the unanimous decisionmaking process would have blocked most external relation activities ${ }^{75}$. With the continuation of the unanimity provision under CFSP, the Commission can be expected to insist on external relations for the EC per se, if not publicly then implicitly ${ }^{76}$. Inasmuch as this will be the case, the interaction in the Council sub-structure is prone to suffer.

73 Art. M. TEU.

74 The economic assistance for Poland belore the period of martial law for example - a clearly politically motivated and politically effective move - would have been given as well without the involvement of EPC in the matter. See: Nuttal, Simon. European Political Co-operation. p. 270.

75 Under the EC provisions, the Community could do with majority outcomes in the Council, thus rendering the procedures relatively efficient. See: Pinder, John. The New European Federalism. p. 58.

76 A good indication of this claim can be seen in the Commission Proposal COM (94) 2 final for a Council Decision conceming the exercise of the Community's external competence at international labour conferences. Having been published on 12 January 1994 it is significant that the EU is not even mentioned. 
As one of the Council officials responsible for the EC-CFSP interaction stated, in the day to day business each tiny step attempting to unify the sub-structures instead of harmonising them, would meet with strong opposition by some Member States ${ }^{\pi}$.

A corrolary of this is the continued deficit in the "full association" of the Commission with the deliberations under CFSP ${ }^{78}$. The Commission's status in the information network Coreu, in the Council meetings and the working-groups differs substantially according to the questions under consideration. During foreign policy deliberations with effects on the EC activities like budgetary questions and development policy as well as questions of export policy and arms exports, the Commission has full rights of participation and discussion. The remaining bulk of topics, however, excludes the Commission and reduces it to a silent observer ${ }^{\text {rg }}$. This turns the exchange of political views in the mysterious "high foreign policy sphere" into a oneway process. While the Commission is obtaining an insight into the Council's/ Member States' conduct of foreign policy, the Council will disregard the fact that the EC pillar has foreign relations of its own.

It may seem all the more surprising may it seem, that the Commission did not unity its approach towards the two facets of external policy making. Until January 1995 it had assigned competences in toreign affairs to two different Commissioners $^{80}$. The Commission under Jacques Santer has even intensified the internal division by assigning competences to different Directorate Generals (DG) ${ }^{81}$ and by increasing the number of Commissioners involved: including the President, the present Commission comprises no less than five members dealing with international politics. On the one hand, the Commission's organisation seems consistent with its claim and vision to be the embryonic government of the European Union. In a conceivable Treaty structure, with the Council deprived of any executive function and the locus of executive authority at the Commission, the present allocation would be operational and make sense. On the other hand such a reform is inconceivable for the

77 Source: Interview with Council Official responsible for the organisation of the CFSP under Council auspices (22/7/1994).

78 This terminology was already used in the EPC-London Report, the SEA and is now again taken up in the Art. J.9. and Art. J.5.3. of the Treaty of European Union.

79 Source: Interview with Council Official responsible for the organisation of the CFSP under Council auspices $(22 / 7 / 1994$.)

80 Whereas Sir Leon Britain had been put in charge of external trade, Mr. Hans van den Broek took responsibility for the external relations including the new common foreign policy. See: Carvel, John/Wolf, Julie. Power struggle as Delors prepares big reshuffle. p.8.

81 DG $I$ is the directorate for external economic relations, DG la the one for external political relations.

82 The Commissioners involved are: Jacques Santer, Hans van den Broek, Sir Leon Brittan, Manuel Marin, Joao de Deus Pinheiro. For more details of their competences see: FAZ 19/January/1995. 
foreseeable future. The Commission's present organisation is thus prone to further confound the EU's performance. While the conflictive teething problems involving an imprecise division of labour seemed to be over ${ }^{89}$, the oft-deplored lack of communication between the DGs means that a division in this highly sensitive field can only be expected to undermine a coherent approach within the Commission ${ }^{24}$. Given that the Commission's workload is likely to increase in the near future, this weakness will be magnified.

By unifying the top-most institutions the TEU has put an end to the blurring of the final decision procedure in the "margins of the Council", but again avoided to reorder the sub-structure. Whereas before, the EPC and EC streams divided completeIy at the level immediately below the Foreign Minister ${ }^{85}$, there is now a differing scope of actors for each pillar. The EC decisions are prepared by the Commission directorates and then discussed by the Council working-groups under COREPER. Under CFSP however, the Political Committee, a relic from EPC, "shall contribute to the definition of policies" without prejudice to the tasks of COREPER (Art. J.8. TEU). Having thus incorporated the Political Committee into the Treaty, the negotiators have nevertheless been unable to make clear how this Political Committee can relate to the Council's sub-structure ${ }^{86}$.

From past experience it can be submitted that the pattern most likely to evolve in the search for closer cohesiveness is a modified form of an old phenomenon, which was termed Politikverflechtung or engrenage ${ }^{87}$. Lacking a real unification, this is at present the only way for the EU to endeavour to achieve a fine-tuning of foreign and external policy. Usually being a typical characteristic of federal political systems $(\text { sic. })^{88}$, interlocking mechanisms in the EC have developed in a number of dimensions :

1. Horizontally within the EC between the Commission and the Council (executive/legislative Politikverflechtung)

83 Carvel, John/Wolf, Julie. Power struggle as Delors prepares big reshutlle. p.8.

84 Lodge, Juliet. EC policy-making: institutional dynamics. p. 11.

85 Nutall, Simon. European Political Co-operation. p. 15.

86 The Declaration No. 27 "on Practical Arrangements in the Field of the Common Foreign and Security Policy", attached to the TEU, promises to examine this question later.

87 The concept of Politikverflechtung was originally developed in the context of the German federal system by Fritz Scharpl and developed further to describe patterns of inter-locking mechanisms on the European level. See: Scharpf, Fritz./Reissert, Bernd./Schnabel, Fritz. Politikverfechtung: Theorie und Empirie des kooperativen Föderalismus in der Bundesrepublik Deutschland. passim. and: Scharpf, Fritz. The Joint Decision Trap: Lessons from German Federalism for European Integration. passim.

88 For a discussion of the European foreign policy in the conlext of federal states, see: Hill, Chrislopher. Shaping a Federal Foreign Policy for Europe. passim. 
2. Horizontally between the Member States in the European Political Cooperation concerning internal affairs as well as foreign policy (intergovernmental Politikverflechtung)

3. Vertically between the EC and the EPC (on external and internal issues) with the famous "EC/Twelve" development (inter-regime Politikverllechtung)

The EU development now nominally reduces the vertical engrenage by shitting the interrelated policy-formulation powers under one the "Union"-umbrella. De facto, however, it leaves the structures separated in two pillars and simply modifies the type of engrenage to an intra-institutional one: The outcome is now an engrenage intra-EU but could equally be seen as an inter-regime Verflechtung EC-CFSP.

The primary function of Politikverflechtung is the creation of a flux of information. In the EC context due to its constitutional role as a key player, the Commission made good use of the information available through the engrenage of the first kind in order to adjust its policy proposals and reach decisions ${ }^{*}$. However, the missing connections under CFSP make a repetition of this success unlikely. First the practice in the Council and its working groups dealing with foreign policy issues prevents the all-level exchange of information. Secondly, the Commission's loss of the sole right of initiative and the unanimity voting in the Council ensures that it loses much of its control over the process.

In addition, it should be borne in mind that the political forces which designed the TEU so inadequately are the same ones which now exert their authority in the existing structure. Under these circumstances it is improbable that the EU institutions will succeed in unifying the structure to an extent which pushes back the constitutional limits. The comment of a Council official acknowledging attempts by the Council and the Commission to achieve the necessary degree in co-ordination has to be seen in this light ${ }^{80}$.

\section{Chapter 4. Conclusion}

The main aim of the CFSP is on the agenda of the European integration process since 1981. Then the European Council acknowledged that the EC would have to break new institutional ground in order to go beyond the achieved co-operation and to increase the capacity to anticipate and shape events in advance instead of purely reacting to them.

89 Ludlov, Peter. The European Commission. pp. 114-115.

90 Source: Interview with Council Official responsible for the organisation of the CFSP under Council auspices (22/7/1994). 
We have to be mindful of the fact that the renaming of the structure and the minor changes undertaken do not in themselves lead to an increase in this capacity. For the capacity to conduct an action in the international system which is more than a "co-ordination reflex", prerequests a clear political conception of what is to be achieved in the short-, medium- and long-term. The foundation of such a conception is a coherent governance characterised by one responsible, democratically answerable and legitimised locus of authority".

Indeed only such an organised constitutional structure could have the chance to gain the diffuse support of the European citizenry which is the basis of all political and social stability in a polity. This in turn is the foundation of the governmental ability to act on any policy-field.

Having disregarded the principle of unicite, demanded by the Commission in the IGCs, the TEU fails to create a governance with characteristics of that kind. Hence, as a whole, the EU structure of governance is too unstable to develop this clear conception.

The consequences of the uncertainties concerning policy-formulation will on the part of Third Countries inevitably amount to an uncertainty if the EU indeed possesses the 'actorness' it claims to have. As an uncertainty of substance this hits right into the heart of the European Union's declared goal to create the capacities to put forward the European interests in international politics.

91 Only a such organised constitutional structure could have the chance to gain the diffuse support of the European citizenry which is the basis of all political and social stability in a polity. This in tum is the fundament of the governmental ability to act on any policy-field. See: Easton, David. A Systern's Analysis of Political Life. passim. 


\section{BIBLIOGRAPHY}

\section{Literature}

Ashley, Richard K. Foreign Policy as Political Performance. In: Intemational Studies Notes. (vol. XIII:) 1987.

Baldwin-Edwards, Martin/Schain, Martin A. The Politics of Immigration. In: Martin BaldwinEdwards/Martin A. Schain (eds.). The Politics of Immigration in Westem Europe. West European Politics. Special Issue. (vol. 17:) 2/1994. pp. 1-16.

Beyer, Peter F. Privatization and the Public Influence of Religion in Global Society. In: Michael Featherstone (ed.). Global Culture. Nationalism, Globalization and Modemity. London/ Newbury Park'New Delhi (Sage Publications) 1990. pp. 373-396.

Bulmer, Simon. Domestic Politics and European Community Policy--Making. In: JCMS. (vol $X X \mid$ :) 4/1983. pp. 349-363.

Pinder John. The New European Federalism. In: Michael Burgess/Alain-G. Gagnon (eds.). Comparative Federaliam and Federation. New York/London/Toronto/Sydney/Tokyol Singapore (Harvester Wheatsheaf) 1993. pp. 45-65.

Curtin, Deirdre. The Constitutional Structure of the Union: A Europe of Bits and Pieces. In: CML Rev. (vol. 30:) 1993. pp. 17-69.

Featherstone, Michael (ed.). Global Culture. Nationalism, Globalization and Modemity. London/Newbury Park/New Dehli (Sage Publications) 1990.

Easton, David. A Systerm's Analysis of Political Life. New York/Sydney/London 1967.

Groom, A.J.R JTaylor, Paul. Functionalism. London (University of London Press) 1975.

Hill, Christopher (ed.). National Foreign Policies and European Political Cooperation. London (RIIAGGeorge Allen \& Unwin) 1983.

Hill, Christopher. Shaping a Federal Foreign Policy for Europe. In: Brian Hocking (ed.). Foreign Relations and Federal States. London/New York (Leicester University Press) 1993. pp. 268-283.

Hill, Christopher. The Capability-Expectations Gap, or Conceptualizing Europe's Intemational Role. Holland, Martin. European Community Integration. London (Pinter Publishers) 1993.

Hocking, Brian (ed.). Foreign Relations and Federal States. London/New York (Leicester University Press) 1993. 
Holland, Martin. European Integration. London (Pinter) 1994.

liestos, Panayiotis. European Political Cooperation. VermontUSA (Avebury/Gower Publ. Comp.) 1987.

Jakobs, Francis/Corbett, Richard/Shackleton, Michael. The European Parliament. Harlow (Longman) 1992.

Lachmann, Per. International Legal Personality of the EC: Capacity and Competence. In: Legal issues of European Integration. The Netherlands. Kluwer, Law \& Taxation Publisher. 1/ 1984. pp. 3-21.

Lodge Juliet (ed.). The European Community and the Challenge of the Future. London (Pinter Publishers) 1993.

Lodge, Juliet. EC Policy-making: institutional dynamics. In: Juliet Lodge (ed.). The European Community and the Challenge of the future. London (Pinter Publishers) 1993. pp. 1-36.

Lodge, Juliet. From civilian power to speaking with a common voice: the transition to a CFSP. In: Juliet Lodge (ed.). The European Community and the Challenge of thu future. pp. 227251.

Lodge, Juliet. Preface. In: Juliet Lodge (ed.). The European Community and the Challenge of the Future. London (Pinter Publishers) 1993. p. xiil-p.xxvi.

Lodge, Juliet. Toward the European Political Community. EEC Summits and European Integration. In: ORBIS. 1975. p. 626-651.

Lodge, Juliet. Transparency and Democratic Legitmacy. In: JCMS. Sept. 1994. lorthcoming.

Ludlov, Peter. The European Commission. In: Robert O. Keohane/Stanley Hoffmann (eds.). The New European Community. Boulder, Colorado/Oxford, UK (Westview Press) 1991. p. 85132.

Mancini, G. Federico. The Making of a Constitution for Europe. In: Robert O. Keohane/ Stanley Hoffmann (eds.). The New European Community. Boulder, Colorado/Oxford, UK (Westview Press) 1991. pp. 177-194.

Mayall, James. Non-intervention, Self-determination and the 'New World Order'. In: International Affairs. (vol 67:) 3/1991. pp. 421-429.

Neuwahl, Nanette A. Joint Participation in Intemational Treaties and The Exercise of Power by The EEC and Its Member States: Mixed Agreements. In: CML Rev. (vol 28:) 1991. pp. 717-740.

Nuttall, Simon. European Political Co-operation. Oxford (Clarendon Press) 1992. 
Nuttall, Simon. Interaction between European Political Co-operation and the European Community. In: Yearbook of European Law. (vol. 7:) 1987. pp. 211-249).

Nuttall, Simon. The Institutional Nelwork and the Instruments of Action. In: Reinhardt Rummel (ed.). Toward Political Union: Planning a Common Foreign and Security Policy in the European Community. Boulder, Colorado (Westview Press) 1992. pp. 55-76.

Pederson, Thomas. The European Union and the EFTA Countries: Enlargement and Integration. London (Pinter Publishers) 1994.

Rhein, Eberhardt. The Community's Extemal Reach. In: Reinhardt Rummel (ed.). Toward Political Union: Planning a Common Foreign and Security Policy in the European Community. Boulder, Colorado (Westview Press) 1992. pp. 29-39.

Rummel, Reinhardt. The Evolution of an Intemational Actor. Westem Europe's New Assertiveness. Boulder, Colorado/Oxtord, UK (Westview Press) 1990.

Scharpf, Fritz. The Joint Decision Trap: Lessons from German Federalism for European Integration. In: Public Administration. (vol. 66:) 1988. pp. 238-278.

Scharpf, Fritz/Reissert, Bemd/Schnabel, Fritz. Politikverflechtung: Theorie und Empine des kooperativen Föderalismus in der Bundesrepublik Deutschland. Kronberg, West-Germany (Scriptor) 1976.

Simmonds, K.R. The Evolution of the Extemal Relations Law of the European Economic Community. In: Intemational and Comparative Law Quartenly. (vol. 28:) Oct./1979. pp. 644668.

Hill, Christopher. The Capability-Expectations Gap, or Conceptualizing Europe's Intemational Role. In: JCMS (vol. 31). No. 3 (September) 1993. pp. 305-321.

Sjöstedt, Gunnar. The Extemal role of the European Community. Famborough (Saxon House) 1977.

Stopford, John M. European Multinational's Competitiveness: implications for trade policy. In: Mayes, David G. (ed.). The Extemal Implications of European Integration. Hemel Hempstead (Havester Wheatsheaf) 1993. pp. 52.78.

Walker, R.B.J. Security, Sovereignty and the Challenge of World Politics. In: Alternatives. (vol. XV:) No. 1 (Winter) 1990. pp. 3-28.

Wannamethee, Phan. The Importance of the EC for South-East Asia: The ASEAN Perspective. In: Schiavone, Giuseppe. Westem Europe and South-East Asia. Basingstoke and London (Macmillan Presse) 1989. p. 20-38. 


\section{Official Documents}

Bulletin of the European Communities. 6/1980.

Bulletin of the European Communities. 6/1983.

Bulletin of the European Communities. 6/1986.

Commission of the European Communities. Europe and the Challenge of Enlargement. In: Bulletin of the European Communities. Supplement 3/1992.

Commission of the European Communities. Political Union. Brussels/Luxembourg. Office for Official Publications of the European Communities 1990.

Commission Proposal COM (94) 2 final from 12 January 1994.

Official Joumal of the European Communities. The issues: OJ C 277 (17 October 1983); OJ C 077 (19 March 1984); OJ C 242/86 (26 September 1986); OJ L 144/80 (10 June 1980); OJ L 308/83 (9 November 1983); OJ L 309/93 (13 December 1993).

Opinion 1/75 of the court of 11 November 1975. In: Reports of cases 1975. pp. 1355-1365. Opinion 1/76 of the court of 26 April 1977. In: Reports of cases 1977. pp. 0741-0762. Opinion 1/78 of the court of 4 October 1979. In: Reports of cases 1979. pp. 2871-2921.

Solemn Declaration on European Union. In: Bulletin of the European Communities. 6/1983. p.24-29.

The Week in Europe. UK Commission publication. 12 January 1995 and 9 February 1995.

\section{Newspapers}

Agence Europe. 11 December 1994.

Beavis, Simon'Cowe, Roger/Buckingham, Lisa. Gatt rules stop British retaliation. In: The Guardian. 26 February 1994. p. 5.

Carvel, John/Wolf, Junie. Power struggle as Delors prepares big reshuffle. In: The Guandian. 16 December 1992 p. 8.

Chamberlian, Greg. US offers Haiti army $\$ 50 \mathrm{~m}$ to restore democracy. In: The Guardian. 18 January 1993. p. 9.

Das Europäische Parlament billigt Santer's Mannschaft. In: FAZ 19/1/1995. pp. 1-2. Long, Simon. Christopher to focus on human rights. The Guardian. 12 March 1994.

Toussaint, Emst. Die Amerikaner sind am Zug. DIE ZEIT. 15 July 1994. p. 8.

Thumann, Michael. Streit um die Sonne. In: DIE ZEIT. 25 February 1994. p. 4.

Woollacott, Martin. Tussle over trade will leave the giants with sore heads. In: The Guardian. 16 February 1994. p. 20. 